\title{
FILAMENT ÚJRAHASZNOSÍTÓ EXTRUDER TERVEZÉSE
}

\author{
Kmetz Barbara \\ MSc gépészmérnök hallgató, Miskolci Egyetem, \\ Gép-és Terméktervezési Intézet, \\ 3515 Miskolc, Miskolc-Egyetemváros, e-mail: kmetzbarbara@gmail.com \\ Takács Ágnes Judit \\ egyetemi docens, Miskolci Egyetem, \\ Gép- és Terméktervezési Intézet, \\ 3515 Miskolc, Miskolc-Egyetemváros, e-mail: takacs.agnes@uni-miskolc.hu
}

\begin{abstract}
Absztrakt
A tanulmányban egy 3D nyomtatóhoz készitendő, filament extrudálására használható készülék megtervezése és összeszerelése kerül leirásra. A 3D nyomtatás napjainkban széleskörben hasznositott technológia. Sajnálatos módon azonban a fö alapanyag a müanyag, a legtöbb esetben nem környezetbarát, viszont újrahasznositható. A filament darabok megfelelő méretre apritás után az anyagtól függően meghatározott hömérsékleten megolvaszthatóak és újra extrudálhatóak. A cikk egy ilyen újrahasznositó készülék tervezését ismerteti.
\end{abstract}

Kulcsszavak: 3D nyomtatás, újrahasznositás, filament, extruder, PID, Solid Edge

\begin{abstract}
In the study we can read about designing and building a filament recycling machine for $3 D$ printers. $3 D$ printing is becoming widely known nowadays, but unfortunately the base material of this technique is polymer, which is not an environmentally friendly material, but it can be recycled in many cases. The filament pieces can be chopped up for the appropriate size and can be heated up to the given temperature, according to the materials specific parameters can be melted down and extruded again. The article deals with designing a recycling machine as described.
\end{abstract}

Keywords: $3 D$ printing, recycling, filament, extruder, PID, Solid Edge

\section{Bevezetés}

A szerkezet felépítését az 1. ábra mutatja. Az extruder készülék számos alkatrészből áll, a tervezés, a szerelés és a vezérlés tervezése is összehangolt munkát igényel. Az extruder készülék vázlata két részt különít el területileg. A felhasználófelületet és magának az extrudernek a munkaterületét. A felhasználófelületen megtalálhatók a különböző vezérlési egységek bekapcsológomjai. A gombok megnyomásával lehet indítani a motor müködését, a ventilátorok müködését, a fütést, valamint egy potméterrel lehet szabályozni a motor sebességét. Az extruder felépítése már jóval összetettebb. A mozgást egy egyszerü szélvédőmotor forgása biztosítja, amely egy tengelykapcsolón van továbbítva. Egy axiális golyóscsapágy veszi fel az extruder nyomóterhelését, majd egy csigafúró következik sorban a tengely mentén. A csigafúró feladata a filament darabok továbbítása. A csigafúró vége egy réz fütőgyürü segítségével felhevül a kívánt hőmérsékletre. A csigafúrót kívülről egy cső borítja. A fütőgyürüt megfelelő szigeteléssel kell ellátni, hogy jobban tartsa a hőt, ez üveggyapot és különböző hőálló ragasztók segítségével 
lehetséges. A felhevített és megolvadt anyag az extruder végéből távozva, hűtés segítségével tekerccsé formálódik.

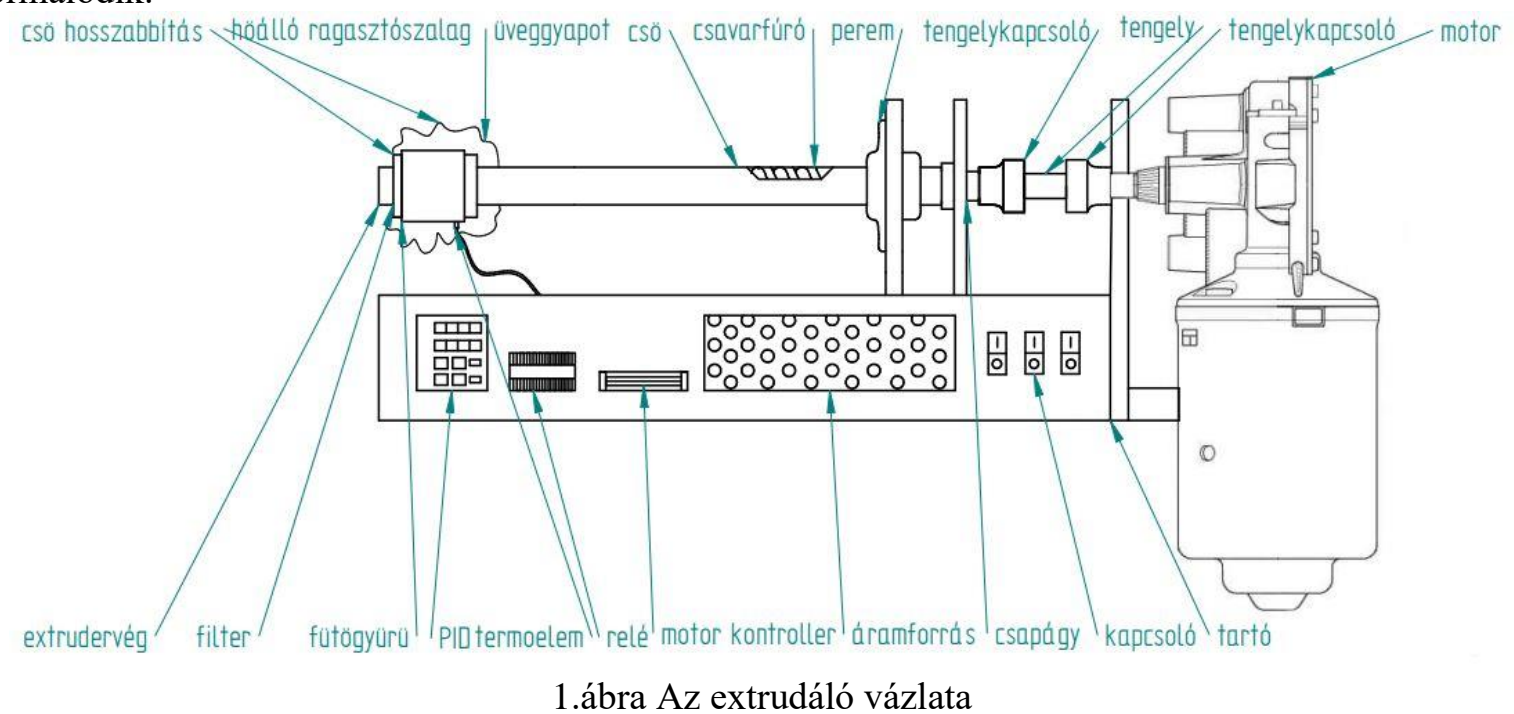

\section{Extruder tartó-mozgató részegysége}

Az extruder egység elkészítésekor az extruder mérete lett először megválasztva és ahhoz lett tervezve a többi alkatrész mérete és funkciója, a megtámasztás és a motor teljesítménye szintén ezen alkatrészhez lett kiválasztva. A felkutatott tanulmányok javaslata szerint elöször a csigafúró méretét kell megválasztani a gép tervezésekor az alapján, hogy milyen és mekkora anyagot, illetve milyen felhasználásra szeretnénk extrudálni [1] [2].

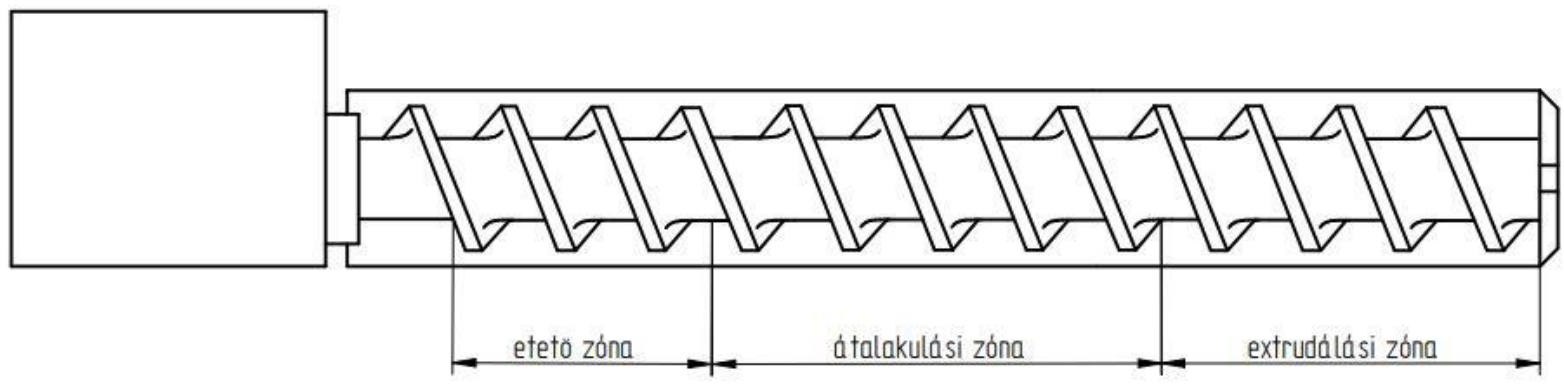

2. ábra. A 3D nyomtatás menete

A csigafúró mérete 16 mm-re lett megválasztva. A korábbiakban említett szükséges maximum 5 mmes filament darabok ebből a méretből következtek, pontosabban mondva így lettek kiválasztva a tervezés kezdeti fázisával. A szakirodalom szerint a csigafúró átmérőjének és az extruder cső hosszának aránya meghatározott kell, hogy legyen [3]. 


\subsection{Az extruder és az extrudercső hosszának meghatározása}

Az extruder méretéhez képest aránypárok figyelembevételével kell meghatározni a megfelelő extruder cső hosszat, amelynek aránya a következö lesz:

- Extruder hossza: $D=16 \mathrm{~mm}$

- Extruder cső hossza: $L=200 \mathrm{~mm}$

Az extruder és a cső hosszának aránya:

Példák szabványos csiga-cső arányokra:

$$
d \div L
$$

$$
1: 10 ; 1: 12 ; 1: 12,5 ; 1: 14 ; 1: 15 ; 1: 16 ; 1: 18 ; 1: 20 ; 1: 22,5 ; 1: 25 \quad[3]
$$

Számított extruder-extruder cső arány:

$$
d \div L \rightarrow 16: 200 \rightarrow 1: 12,5
$$

A választott szabályos aránypár:12,5 lett. A pontos, végső hosszat a szerkezet megtervezése közben kapja, a hosszú méretnek hála könnyen a kívánt méretre lehet igazítani az extrudert. Az extruder a $18 \mathrm{~mm}$-es külső átmérőjü megvásárolt csőbe megfelelően beleilleszthető, a cső fala és a fúró se nem szorul se nem túl lazán illeszkedik, ez fontos komponense a megfelelő, egyenletes extrudálásnak. A fúró háza $200 \mathrm{~mm}$ hosszúra lett tervezve. A $200 \mathrm{~mm}$-es alkatrész tudatosan lett kiválasztva, a szerkezet számára megfelelő méretüre. Az extruder és a cső kapcsolatából, valamint a rendelkezésre álló geometriájukból következik, hogy számolhatók különböző átfolyási sebességek. Az etető zónánál a következő fejezetrészben leírt módon lehet szilárd átfolyási sebességet számítani az extruder és a cső geometriájának felhasználásával.

\subsection{Szilárd átfolyási sebesség}

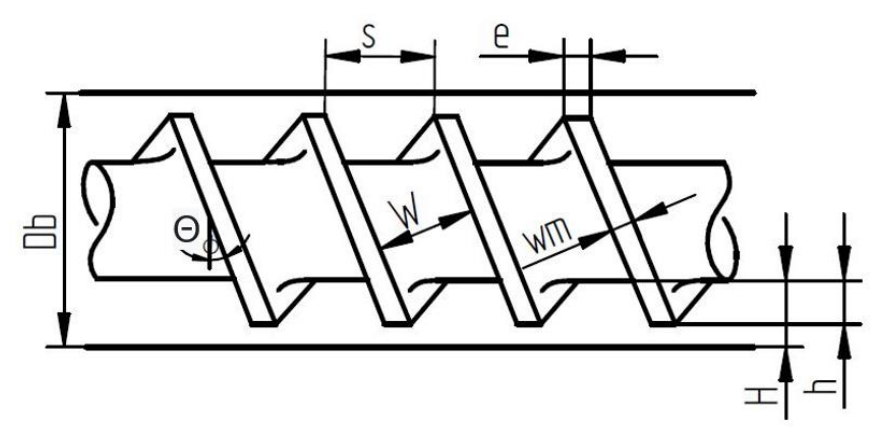

3. ábra. Extruder geometria

A rendelkezésre álló geometriák alapján számítható a szilárd szállítási sebesség. A geometria következő elemeire lesz szükség a kalkuláláshoz [4]:

- Cső átmérő: $D_{b}=17 \mathrm{~mm}=0,017 \mathrm{~m}$.

- Csavar menet: $s=12 \mathrm{~mm}=0,012 \mathrm{~m}$.

- Menetek száma: $v=1$. 
- Menet szélesség: $w_{m}=10 \mathrm{~mm}=0,01 \mathrm{~m}$.

- Két menet közötti csatorna: $W=15 \mathrm{~mm}=0,015 \mathrm{~m}$.

- Etető zóna mélysége a csőben: $H=6,5 \mathrm{~mm}=0,0065 \mathrm{~m}$.

- PLA szállítási hatásfok: $h_{F, P L A}=0,395$.

- ABS szállítási hatásfok: $h_{F, A B S}=0,235$.

- Fúró sebessége: $N=50 \mathrm{rpm}=501 / \mathrm{min}=30001 / \mathrm{h}$.

- Polimer térfogatsürüsége: $\quad \rho_{0, P L A}=1,24 \mathrm{~g} / \mathrm{cm}^{3}$

$$
\begin{aligned}
& \rho_{0, P L A}=1240 \mathrm{~kg} / \mathrm{m}^{3} \\
& \rho_{0, A B S}=1,06 \mathrm{~g} / \mathrm{cm}^{3} \\
& \rho_{0, A B S}=1060 \mathrm{~kg} / \mathrm{m}^{3} .
\end{aligned}
$$

- Szilárd átfolyási sebesség egyenlete és megoldása:

$$
\dot{m}=60 \cdot \rho_{0, P L A, A B S} \cdot N \cdot h_{F} \cdot \pi^{2} \cdot H \cdot D_{b} \cdot\left(D_{b}-H\right) \cdot \frac{W}{W+w_{m}} \cdot \sin \theta \cdot \cos \theta
$$

- $\Theta$ hélix szög kiszámítása:

$$
\theta=30^{\circ}=30^{\circ} \cdot \frac{\pi}{180}=0,5235987756 \mathrm{rad}
$$

- Átfolyási sebesség kiszámítása a két anyagra:

$$
\begin{gathered}
\dot{m}=60 \cdot \rho_{0, P L A} \cdot N \cdot h_{F} \cdot \pi^{2} \cdot H \cdot D_{b} \cdot\left(D_{b}-H\right) \cdot \frac{W}{W+w_{m}} \cdot \sin \theta \cdot \cos \theta \\
\dot{m}=463,06^{\circ} \frac{\mathrm{kg}}{\mathrm{h}} \\
\dot{m}=60 \cdot \rho_{0, A B S} \cdot N \cdot h_{F} \cdot \pi^{2} \cdot H \cdot D_{b} \cdot\left(D_{b}-H\right) \cdot \frac{\mathrm{W}}{\mathrm{W}+w_{m}} \cdot \sin \theta \cdot \cos \theta \\
\dot{m}=395,8439 \frac{\mathrm{kg}}{\mathrm{h}}
\end{gathered}
$$

A kapott értékek a teljes cső keresztmetszeten $\left(226,98 \mathrm{~mm}^{2}\right)$ átmenő lehetséges szilárd átfolyást szemléltetik. A valóságban a jelen cső keresztmetszetét le kell csökkenteni a kimeneti szakaszon, ez azt jelenti, hogy a szilárd átfolyási érték is arányosan fog csökkenni. A tárgyalt új csőkeresztmetszet $0,01767 \mathrm{~mm}^{2}$, amelyre a vonatkoztatott számítások elvégzése után (egyszerü aránypár felírása) a következö értékeket kaptuk. A számításokból megállapítható, hogy a politejsav szilárd átfolyási sebessége közelítőleg 18,5732 kg/h lesz, az akrilnitril-butadién-sztirol átfolyási sebessége pedig közelítőleg $15,8457 \mathrm{~kg} / \mathrm{h}$ lesz az előtervezés szerint. A két anyag hasonló tulajdonságaiból (pl.: sürüség) adódik, hogy a két számításra közel azonos érték lett az eredmény. Ezen számítások segítségével megbecsülhető, hogy óránként mennyi filamentet lesz képes legyártani az újrahasznosító gép [5]. A számítások szilárd 
anyagra vetített értékei a valóságban töredékére fogják csökkenteni az átfolyási mennyiséget az olvasztás és a hütés folyamata miatt.

A számított terület a hasznos terület az összedarabolt anyag adagolása szempontjából, ezen a keresztmetszeten történik meg a hulladék beöntése. Ezen felületet kell összekötni a daraboló alsó felületével. Az összekötés egy adagoló elemmel lett megoldva. Az adagoló elem egy Solid Edge-ben megtervezett, majd 3D nyomtatott elem, mivel ez a terület nincs kitéve nagy hőmérsékletnek.

A cső végéből kivezet a fúró vége és négyszög hasábban tovább halad a motor felé. Az extruder tengelyének a végét és a motor tengelyét össze kell kötni valamilyen tengely kötéssel. Ezen feladatra megfelel egy egyszerü tengelyt összekapcsoló alkatrész, amelynek egyik vége a fúró végébe illik, a másik vége pedig a motor tengelyének a végére. Jelen esetben egy egyszerü négyszögletű tengely volt az említett összekötő elem. A motor kiválasztásánál hasonló irodalmak és hobby tervezők munkáit is figyelembe vettem és számos javaslat alapján egy egyszerü ablaktörlő motor lett kiválasztva a hajtáshoz (medium.com ) (www.filastruder.com) [6] [7].

Az eddig elméletben megtervezett szerkezet alkatrészeinek szüksége van egy biztos alapra, amelyre fel lehet szerelni az alkatrészeket és biztosítani lehet, hogy az egyes elemek ne mozduljanak el. Ez az alap Hilti szerelősínből lett elkészítve, mert ez az elem már megfelelő tartást ad a szerkezetnek. Ezen kívül egy külön tartó elemhez lett tervezve a cső rögzítése és a benne átfutó extruder, a motor tengelyét pedig szintén egy külön tartó elem támasztja meg. A pozícionálást a rögzítő perem és a menetes kötőelem segítik, amelyek pontosan ráillenek az alkatrészekre. A cső vége egy axiális golyós csapágyban végződik. Ennek a megoldásnak a megindoklása mögött a visszarúgás elleni védelem áll. Az extruder spirál egy tengely irányú nyomást fejt ki a motor felé. Ez a nyomás a motor irányában támaszkodik fel, a csapágy felveszi ezt a támasztást (nyomást) és megszünteti a motor terhelését. A tengely irányú terhelés megszűnésével a hajtás nem kap ilyen irányú terhelést. Ez a védelem azért fontos, mert a motor és a hajtása nem ilyen tengely irányú nyomás felvételére van megtervezve (eredetileg gépjármủ ablaktörlő motor), hanem forgó mozgás végzésére, a forgó terheléseket tudja megfelelően kezelni. Ezen csapágyvédelem eltünteti az esetleges tengely irányú terhelésből adódó kopást, élettartam csökkenést.

Az említett terhelés miatt célszerü megvizsgálni a csapágyat érő erőhatásokat és csapágy élettartamot számítani.

\section{Fütő részegység}

A fütő részegység megtervezése és összeszerelése a legbonyolultabb része a szerkezetnek, hiszen nemcsak a mechanikus elemeket, hanem az elektronika müködését is össze kell hangolni, a kapcsolások elkészítése pedig kisebb nehézségeket vethet fel villamossági ismeretek hiányában. A részegység felsorolt alkatrészeit sorban tekintve a legkönnyebb megérteni ezen rész müködését. A $18 \mathrm{~mm}$ külső átméröjü cső végére egy további cső hosszabbítás kerül felszerelésre, mert szükség van egy olyan pár cm-es szakaszra, amelynek a hővezetése lényegesen jobb, mint a rozsdamentes acélnak. Ez a szakasz lesz ugyanis felfütve a kívánt olvasztási hőmérsékletre, ezért erre a célra egy rézből készült $50 \mathrm{~mm}$-es hosszabbítás kerül (edge.rit.edu) (www.printfromsd3d.com ) [8] [9]. A réz csődarabra felhelyezésre kerül a fütőgyürü, amely a tényleges hevítést végzi a szenzor és a termoelem visszajelzése alapján. Az említett termoelem érzékeli a hőmérsékletet és továbbítja az információt a szenzornak, miszerint füteni vagy hüteni kell-e a fütőgyürüt. A termoelem a réz cső hosszabbításba van rögzítve, mivel egy $3 \mathrm{~mm}$-es kifúrt lyukon keresztül van a csőbe engedve, hogy valós értékủ hőmérsékletet mutasson. A réz csőhosszabbítás után már csak egy elem kapcsolódik a szerkezethez, ez pedig az extrudervég. Ezen az alkatrészen keresztül távozik a megolvasztott anyag a gépböl és szilárdul meg újból. 


\section{Az elektronika összeszerelése}

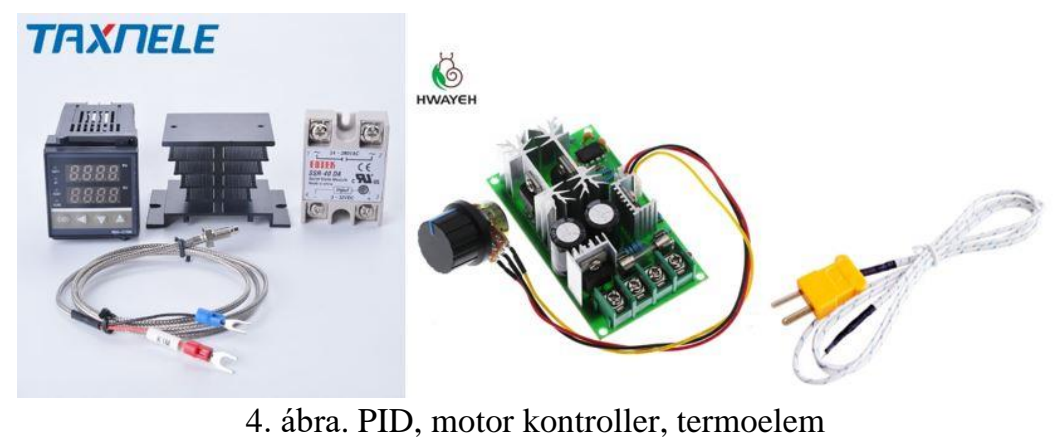

A fejezet az elektromos alkatrészek összehangolásáról és kapcsolásáról szól. Minden felsorolt elektromos alkatrész müködése az áramellátástól függ, ezért a megfelelő tápegység kiválasztása határozza meg a müködést. Minden egyes elektromos alkatrészt figyelembe véve a tápegységet kicsivel erősebbnek kell megválasztani, hogy mindenképpen elbírja a motort károsodás és kisülés nélkül. A választott tápegység $12 \mathrm{~V}$ feszültségen müködik $240 \mathrm{~W}$ teljesítménnyel. A tápegység különböző lábaira lehet kötni az alkatrészeket.

A három kézi kapcsoló fogja beindítani az egész szerkezet működését (ad áramot a rendszernek), indítja a motor vezérlését a kontrolleren keresztül. A beszerelt motor kontroller egy olyan kontroller, amellyel a motor sebességét lehet szabályozni, az egyik említett kapcsolón keresztül van az áramforrásra kötve, valamint direktben a tápegység másik lábára, az egyik $\mathrm{V}$ pluszra van kapcsolva. A motor a kontrolleren keresztül kap áramellátást. Szintén a kontrollerre van kötve a két hütő ventilátor, amelyek közül az egyik a motor hütéséért, a másik pedig az extruderből kijövő filament hütéséért felelős. A második kapcsolóra van kötve a PID hőmérséklet szenzor, amely így szintén kap áramot a müködéshez. A fütőgyürü $230 \mathrm{~V}$ feszültségü, a PID szenzor viszont csak $12 \mathrm{~V}$ feszültségen müködik, ezért a relé feladata a fütőgyürü $230 \mathrm{~V}$-ját összekötni a PID szenzor csupán 12 V-jával. A relé másik két portja az áramellátáshoz kapcsolódik föld és $230 \mathrm{~V}$-ként. A relé záráskor a PID jele alapján felhevíti a fütőgyürüt, amikor azonban nem kapcsol, a hevítés nem történik meg. A vezérlés az itt leírtak alapján müködik.
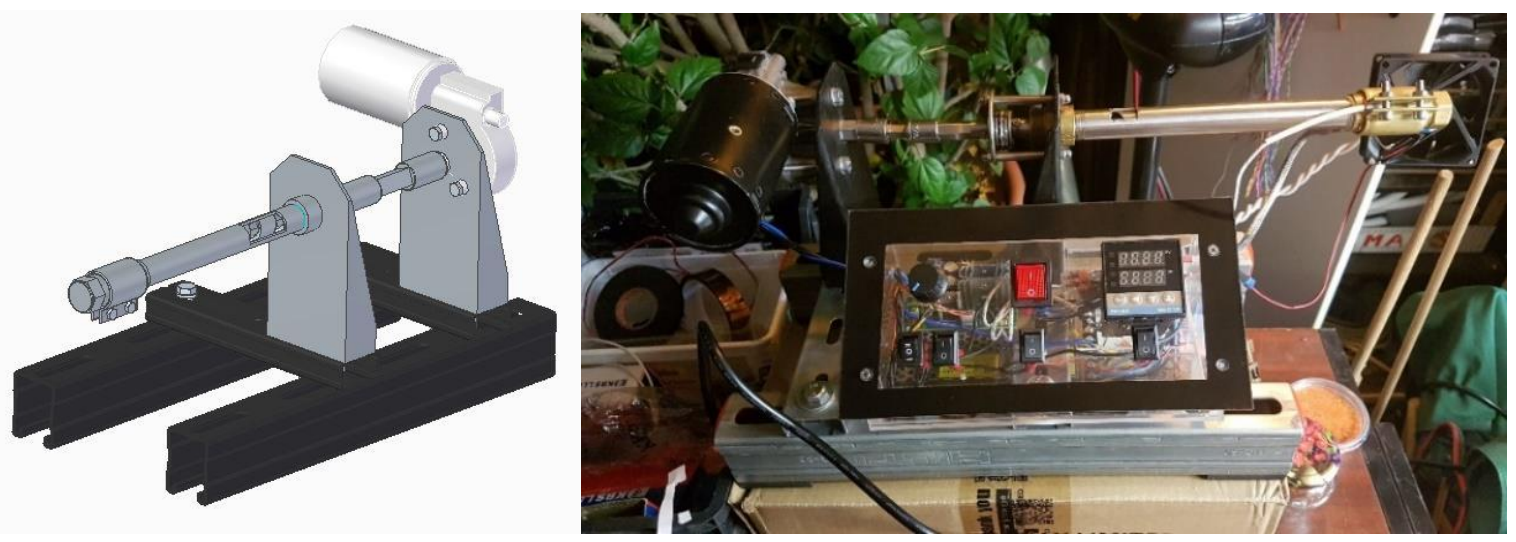

5. ábra. Extruder modell és készülék 


\section{5. Összefoglalás}

A kutatás kitekintett a szerkezet vázlatának és elemeinek meghatározására, majd a szükséges számítások elvégzése is megtörtént, mint a hossz arányok és az átfolyási sebesség megállapítása. Ezután a fütő részegység és az elektronika került részletes ismertetésre és a szerkezet modellje valamint megvalósított prototípusa is megtalálható a cikkben. A kutatás eredménye egy tesztelésre kész készülék helyesen müködő vezérléssel és felhasználó felülettel.

\section{Köszönetnyilvánítás}

„Az Innovációs és Technológiai Minisztérium ÚNKP-20-2-I. Kódszámú Új Nemzeti Kiválóság Programjának a Nemzeti Kutatási, Fejlesztési és Innovációs Alapból finanszírozott szakmai támogatásával készült."

\section{Irodalom}

[1] Michaeli, W.: Extrusion Dies for Plastics and Rubber, ISBN 3446161902, Hanser Publisher, Germany, 1992

[2] Lafleur, P., Vergnes, B.: Polymer Extrusion, ISBN 9781848216501, ISTE Ltd. and John Wiley \& Sons, Inc., USA, Great Brittain, 2014 https://doi.org/10.1002/9781118827123

[3] Wagner, J., Mount, E., Giles, H.: Extrusion: The Definitive Processing Guide and Handbook, ISBN 9781437734812, Elsevier, Inc., USA, 2014 https://doi.org/10.1016/B978-1-4377-3481-2.00055-7

[4] Birley, A., Haworth B., Batchelor, J.: Physics of Plastics Processing, Properties and Materials Engineering, Chapter 4., Hanser Publisher, Munich, Cincinatti, 1992

[5] Rao, N., Schott, N.: Understanding Plastics Engineering Calculations, ISBN 9781569905098, pp: 67-70, Hanser Publisher, Munich, Cincinatti, 2012 https://doi.org/10.3139/9783446431492.fm

[6] https://www.filastruder.com/ Letöltve: 2020.12.10.

[7] https://medium.com/endless-filament/make-your-filament-at-home-for-cheap-6c908bb09922 Letöltve: 2020.12 .10$.

[8] http://edge.rit.edu/edge/P15551/public/Detailed\%20Design Letöltve: 2020.12.10.

[9] https://www.printfromsd3d.com/projects/filastruder-3d-printing-filament-maker 